\title{
Evaluation of Arbuscular Mycorrhiza Fungi Species for Their Efficiency Towards Nutrient Acquisition in Rhizospheric Soil of Maize
}

\author{
Kasturikasen Beura*, Mahendra Singh, Amit Kumar Pradhan, Rajiv Rakshit and Manohar Lal
}

Dept. of Soil Science and Agricultural Chemistry, Bihar Agricultural University, Sabour, Bihar (813 210), India

\section{Article History}

Manuscript No. AR1505b

Received in $19^{\text {th }}$ December, 2015

Received in revised form $15^{\text {th }}$ January, 2016

Accepted in final form $6^{\text {th }}$ February, 2016

\section{Correspondence to}

*E-mail: beura.kasturi88@gmail.com

\section{Keywords}

VAM, soil nutrients, rhizospheric region, maize

\begin{abstract}
An investigation was carried out to evaluate the response of selected species of mycorrhizae for nutrient acquisition and phosphorus uptake by maize in an alluvial soils of Bihar. The study was undertaken during 2013 wet season (July to December) in a net-house at Bihar Agricultural University. Six treatments along with a control treatment were maintained with three replications for the experiment. Five species of AM fungi collected from TERI (The Energy and Resources Institute) along with a local species from long term litchi orchard (Muzaffarpur), were evaluated on the basis of nutrient acquisition in the soil rhizospeheric region for maize crop. The results obtained clearly show that of all the species of mycorrhizae taken under consideration, Glomus mosseae was found to perform better in terms of nutrient acquisition and uptake of $\mathrm{P}$ to plant. The maximum $P$ concentration $\left(7.65 \mathrm{mg} \mathrm{kg}^{-1}\right)$, organic carbon $(0.60 \%)$ and $\mathrm{Zn}$ Concentration $\left(6.48 \mathrm{mg} \mathrm{kg}^{-1}\right)$ and $\mathrm{P}$ uptake (was also found with the application of G. mosseae. The AM (Arbuscular Mycorrhiza) species significantly increased the released of $\mathrm{P}$ and micronutrients in the soil of rhizospheric region of maize plant. The beneficial effect was more pronounced for the treatment in case of Glomus mossae among all the other species used. This may be due to the higher solubilization power of Glomus mossae for soil nutrients than other species.
\end{abstract}

\section{Introduction}

Now-a-days maize is one of the valuable crops in Bihar. Phosphorus is known to be one of the most essential elements for plant growth and development after nitrogen for the said crop. Effective nutrient management particularly for phosphorus and micronutrients is important to optimize crop yield potential, reduce production costs and decrease the risk of environmental damage. Arbuscular Mychorriza (AM) fungi are one of the sustainable options for increasing the nutrient availability in rhizospheric region of crops. The beneficial effects of AM and other microorganisms on plant performance and soil health can be very important for the sustainable management of agricultural ecosystems (Smith and Smith, 2011 and Gianinazzi et al., 2010). Almost all higher plants in the terrestrial ecosystem are known to be associated with mycorrhizal fungi (Smith et al., 1997; Hata et al., 2010). Perhaps AM fungi synthesize and secrete organic substances (siderophores) which increase the desorption of $\mathrm{P}$ in labile soil $\mathrm{P}$ pools. With organic acids, AM fungi can solubilize low-soluble and insoluble $\mathrm{P}$ sources which are a part of the crystalline structure of minerals in the soil (Anonymous, 2005).
In many ecosystems, these symbiotic fungi play an important role in sustaining plant productivity by increasing its nutrients and water uptake from the soil (Anup et al., 2014 and Mobasser and Moradgholi, 2012) Roots and rhizosphere are the regions of interest for their symbiotic efficiency. By colonizing the roots, they bring about several changes in the metabolic activity of the plants, resulting in stimulation of various enzymes. This leads to the modification of the rhizosphere, wherein plenty of micro-organisms survive with their mutual interactions. Mycorrhizosphere may bring about the changes in microbial population and can also contribute for the enhanced growth and nutrition of crop plants. Soil nutrients are highly activated under mycorrhizosphere and yield several positive responses. Hence, it is essential to study the understanding of the AM induced changes in the rhizosphere. The role of $\mathrm{AM}$ in the acquisition of nutrients from the soil has been long recognized and well documented. It has been reported that plant dependency to mycorrhizal fungi depends on the level of soil fertility and receptivity of soil to inoculants (Covacevich and Echeverria, 2008).With this background, the present study was undertaken to evaluate different AM species for their efficiency 
towards nutrient acquisition in rhizospheric soil in maize crop.

\section{Materials and Methods}

The present study was undertaken to screen the AM fungi for maize crop during the rabi season of 2013-14 with a promising var. DHM-117, at Bihar Agricultural University, Sabour, Bhagalpur, India. Inoculums of the five AM species viz., Glomus mosseae, Glomus coronatum, Glomus intraradices, Gigaspora decipiens and Gigaspora margarita were commercial products of The Energy Resource Institute (TERI), New Delhi, India. The products consisted of fragments of colonized roots and spores of AM fungi in a vermiculite substrate. One uncharacterized local inoculum (control) was collected from the maize and litchi farm of Bihar Agricultural University, Sabour. The substrate used for the experiment consisted of soil from the Bihar Agricultural University, research farm and river bed sand of the Ganges (w/w, 3:1). The soil was collected from the surface $(0-15 \mathrm{~cm})$ and passed through a $2.00 \mathrm{~mm}$ aperture sieve to remove roots and debris. The river bed sand was thoroughly washed with tap water to remove salt. The substrate mixture was completely sterilized by autoclaving over $1 \mathrm{hr}$ with stepwise increase in temperature till the center reached $120{ }^{\circ} \mathrm{C}$ (kept for 30 minutes). The substrate used for the pot experiment was loamy sand in texture, having a $\mathrm{pH}$ of 7.2 and $\mathrm{EC}$ of $0.22 \mathrm{dS} \mathrm{m}^{-1}$. The organic carbon content of the substrate was $0.56 \%$, and the available nitrogen, phosphorus and potassium content was found 180.77, 25.89 and $220.66 \mathrm{~kg} \mathrm{ha}^{-1}$, respectively.

Seeds were surface-sterilized by treatment with a 1:1 mixture of $\mathrm{H}_{2} \mathrm{O}_{2}$ and absolute ethanol for 2 minutes followed by a treatment with $0.05 \% \mathrm{HgCl}_{2}$ for 1 minute. The sterilizing agents were drained aseptically, and the seeds were washed for 10-12 times in sterile distilled water to remove all traces of the chemicals. Earthen pots of $15 \mathrm{~cm}$ height and $30 \mathrm{~cm}$ diameter were filled with $10 \mathrm{~kg}$ of sterilized substrate. All AM species were maintained in the pots with five replications each. The following treatment structure was formulated for the study: $\mathrm{T}_{1}-G$. mosseae, $\mathrm{T}_{2}-G$. coronatum, $\mathrm{T}_{3}-G$. intraradices, $\mathrm{T}_{4}-G$. decipiens, $\mathrm{T}_{5}$-G. margarita, $\mathrm{T}_{6}$-Local (uncharacterized inoculum) and $\mathrm{T}_{7}$-control (without inoculum). About $5 \mathrm{~g}$ of the AM inoculum source (containing and 8-10 spores $\mathrm{g}^{-1}$ ) was mixed with the upper $4 \mathrm{~cm}$ of the substrate in each pot. In each pot, 4 sterile seeds of maize (var. DHM 117) were planted. Once in every 15 days, each pot was treated with $20 \mathrm{ml}$ of Hoagland solution minus phosphate (Hoagland and Arnon, 1938). One plant from each pot was uprooted after 75 days of sowing. After measuring the shoot height they were kept in a hot air oven to dry at $105{ }^{\circ} \mathrm{C}$ for 72 hours until they attained a constant weight. The experiment was laid out in a completely randomized block design with three replications.
The cultivated soil was collected from Bihar Agricultural University Farm. The soil used in the pot experiment was air-dried, ground and sieved through a $2 \mathrm{~mm}$ sieve, and then stored in plastic bags. An initial soil sample was analyzed for different physico-chemical parameters following the standard protocol. The $\mathrm{pH}$ and electrical conductivity of the soil was determined by Glass electrode $\mathrm{pH}$ meter and Conductivity meter (Jackson, 1973) respectively. The textural class was determined by (Bouyoucos, 1962). Rhizospheric soil samples were analyzed for mineral-N by (Subbiah and Asija, 1956), available P by (Olsen et al., 1957), available-K by (Black, 1965), Organic Carbon by (Walkley and Black, 1934) and available cationic micronutrients by (Lindsay and Norvell, 1978) after the harvesting of maize crop. Analysis of variance (ANOVA) was performed as described by Gomez and Gomez (1984) to determine the effects of various treatments. Critical difference $(\mathrm{CD})$ at 5\% level of probability and $\mathrm{P}$ values was used to examine differences among treatment means.

\section{Results and Discussion}

\subsection{Physico-chemical characterization of the experimental} soil

The chemical properties and texture of the soil before starting of the experiment were shown in Table 1. The soil was neutral to slightly alkaline in reaction. EC of soil was $0.257 \mathrm{dSm}^{-1}$. The experimental soil was silty clay loam in texture. The soil was characterized with a low organic matter content of $0.56 \%$, having low available $\mathrm{N}, \mathrm{P}$ and $\mathrm{K}$ of $104,6.1$ and $88.3 \mathrm{mg} \mathrm{kg}^{-1}$, respectively. The DTPA extractable cationic micronutrients were found out to be $4.51,0.78,16.13$ and $13.91 \mathrm{mg} \mathrm{kg}^{-1}$ for $\mathrm{Zn}, \mathrm{Cu}, \mathrm{Fe}$ and $\mathrm{Mn}$, respectively.

Figure 1 showed that the $\mathrm{pH}$ values of the studied soil were affected by the application of AM species indicating that the inoculation of AM had a favorable effect on lowering the soil

\begin{tabular}{|c|c|c|c|}
\hline Parameters & Value & Parameters & Value \\
\hline Soil texture & $\begin{array}{l}\text { Silty clay } \\
\text { loam }\end{array}$ & $\begin{array}{c}\text { Organic carbon } \\
(\%)\end{array}$ & 0.56 \\
\hline pHw $(1: 2.5)$ & 7.66 & $\begin{array}{l}\text { Bulk density } \\
\qquad\left(\mathrm{g} \mathrm{cc}^{-1}\right)\end{array}$ & 1.45 \\
\hline $\begin{array}{l}\text { Electrical } \\
\text { conductivity }\left(\mathrm{dSm}^{-1}\right)\end{array}$ & 0.257 & $\mathrm{Zn}\left(\mathrm{mg} \mathrm{kg}^{-1}\right)$ & 4.51 \\
\hline $\begin{array}{l}\text { Available nitrogen } \\
\left(\mathrm{mg} \mathrm{kg}^{-1}\right)\end{array}$ & 104 & $\mathrm{Cu}\left(\mathrm{mg} \mathrm{kg}^{-1}\right)$ & 0.78 \\
\hline $\begin{array}{l}\text { Available phospho- } \\
\left.\text { rus (mg kg } \mathrm{mg}^{-1}\right)\end{array}$ & 6.1 & $\mathrm{Fe}\left(\mathrm{mg} \mathrm{kg}^{-1}\right)$ & 16.13 \\
\hline $\begin{array}{l}\text { Available potas- } \\
\text { sium }\left(\mathrm{mg} \mathrm{kg}^{-1}\right)\end{array}$ & 88.3 & $\operatorname{Mn}\left(\mathrm{mg} \mathrm{kg}^{-1}\right)$ & 13.91 \\
\hline
\end{tabular}


$\mathrm{pH}$ in rhizospheric region. The $\mathrm{pH}$ was at its lowest value in case of Glomus mosseae (7.49). This finding might be due to the beneficial effect of organic acids produced by the root exudates and AM species during its life cycle. The similar results were also obtained by Rai et al., 2013; El-Fayoumy and Ramadan, 2002.

Data in Table 2 showed that addition of AM inoculation increased soil P concentration which was significantly higher over control. Available P was increased by $41.4 \%$ under Glomus mosseae over control treatment (Table 2). Glomus mosseae had pronounced effect for phosphorus acquisition in soil. A parallel trend was also seen in case of available $\mathrm{N}$, $\mathrm{K}$ and organic carbon status of soil (Hodge and Fitter, 2010 and Olsson et al., 2010). The increasing root length value and

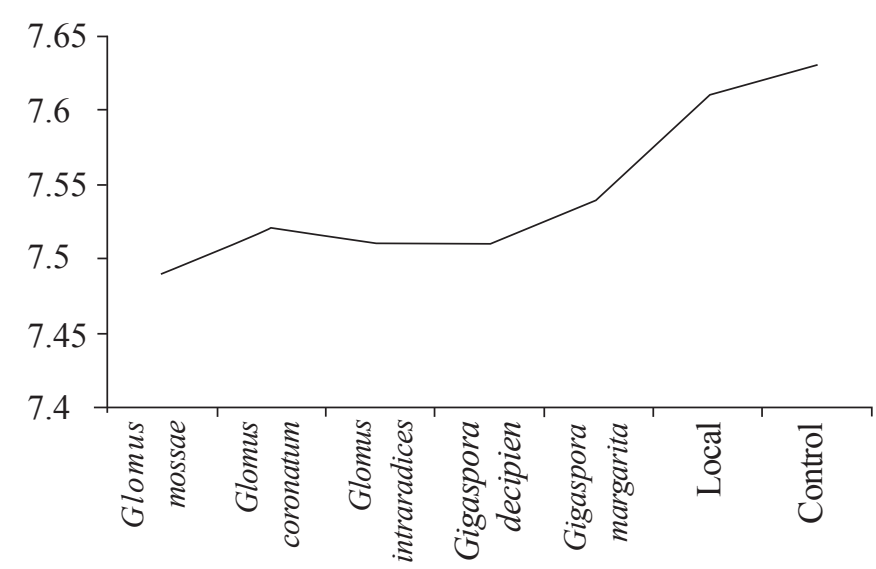

Figure 1: $\mathrm{pH}$ of the post harvest soil

\begin{tabular}{|c|c|c|c|c|}
\hline AM Species & $\begin{array}{c}\text { Available } \\
\mathrm{N}\left(\mathrm{mg} \mathrm{kg}^{-1}\right)\end{array}$ & $\begin{array}{c}\text { Available } \\
\text { P } \\
\left(\mathrm{mg} \mathrm{kg}^{-1}\right)\end{array}$ & $\begin{array}{c}\text { Avail- } \\
\text { able K } \\
(\mathrm{mg} \\
\left.\mathrm{kg}^{-1}\right)\end{array}$ & $\begin{array}{c}\text { Organic } \\
\text { Carbon } \\
(\%)\end{array}$ \\
\hline $\begin{array}{l}\text { Glomus } \\
\text { mossae }\end{array}$ & 99.32 & 7.65 & 101.33 & 0.60 \\
\hline $\begin{array}{l}\text { Glomus } \\
\text { coronatum }\end{array}$ & 98.32 & 7.1 & 97.83 & 0.59 \\
\hline $\begin{array}{l}\text { Glomus } \\
\text { intraradices }\end{array}$ & 95.47 & 6.93 & 96.93 & 0.59 \\
\hline $\begin{array}{l}\text { Gigaspora } \\
\text { decipien }\end{array}$ & 93.28 & 6.75 & 94.04 & 0.58 \\
\hline $\begin{array}{l}\text { Gigaspora } \\
\text { margarita }\end{array}$ & 91.00 & 6.57 & 90.53 & 0.58 \\
\hline Local & 88.0 & 5.6 & 87.3 & 0.57 \\
\hline Control & 86.33 & 5.41 & 76.24 & 0.51 \\
\hline $\begin{array}{l}\mathrm{CD} \\
(p=0.05)\end{array}$ & NS & 0.36 & 2.44 & NS \\
\hline
\end{tabular}

root biomass observed in the study resulted in greater root exudates and readily metabolizable $\mathrm{C}$. These results were also in accordance with the findings of Rakshit and Bhadoria, 2010 and Chu et al., 2013. Glomus mosseae was found to be as much compatible strain than other AM strains used for maize crop. The similar results were also reported by Tanwar and Aggarwal, 2013 and Parewa et al., 2010.

Data in Table 3 also indicated that the concentrations of $\mathrm{Fe}$, $\mathrm{Mn}, \mathrm{Zn}$ and $\mathrm{Cu}$ were significantly increased in case of applied AM species over control treatment. DTPA extractable Fe and Mn were slightly affected by mycorrizal inoculation than non-inoculated control. But the DTPA extractable $\mathrm{Zn}$ and $\mathrm{Cu}$ were increased in the soil treated with AM fungi. Higher root biomass mediated exudation and this was perhaps the most important reason for the increase. Among all the AM species, Glomus mosseae had pronounced effect for cationic micronutrient acquisition in soil. This result was in consonance with the findings of Archana et al., 2012; Balakrishnan and Subramanian, 2012; Habasy and Abo-Zaid, 2005. Glomus mossae showed the highest acquisition of cationic micronutrients in soil rhizosphere among all the other species.

\subsection{P uptake}

P uptake was found to be higher with the application of $G$. mosseae, than G. coronatum and G. decipiens (Figure 2). AMF induced enhancement in phosphatase activity could possibly mediate the release of organically bound phosphorous and hence increasing transport and uptake of phosphorous in AMF inoculated plants. Increased activity of phosphatases has direct bearing with the phosphorus metabolism. Bhadraiah

\begin{tabular}{|c|c|c|c|c|}
\hline AM Species & $\begin{array}{c}\text { Zinc } \\
\left(\mathrm{mg} \mathrm{kg}^{-1}\right)\end{array}$ & $\begin{array}{c}\text { Copper } \\
\left(\mathrm{mg} \mathrm{kg}^{-1}\right)\end{array}$ & $\begin{array}{l}\text { Iron } \\
(\mathrm{mg} \\
\left.\mathrm{kg}^{-1}\right)\end{array}$ & $\begin{array}{l}\text { Manga- } \\
\text { nese } \\
\left(\mathrm{mg} \mathrm{kg}^{-1}\right)\end{array}$ \\
\hline $\begin{array}{l}\text { Glomus } \\
\text { mossae }\end{array}$ & 6.48 & 0.93 & 18.18 & 15.32 \\
\hline $\begin{array}{l}\text { Glomus } \\
\text { coronatum }\end{array}$ & 5.37 & 0.85 & 17.98 & 15.11 \\
\hline $\begin{array}{l}\text { Glomus } \\
\text { intraradices }\end{array}$ & 4.98 & 0.83 & 17.82 & 14.43 \\
\hline $\begin{array}{l}\text { Gigaspora } \\
\text { decipien }\end{array}$ & 4.74 & 0.77 & 17.53 & 14.38 \\
\hline $\begin{array}{l}\text { Gigaspora } \\
\text { margarita }\end{array}$ & 4.56 & 0.76 & 16.86 & 13.98 \\
\hline Local & 4.2 & 0.74 & 16.77 & 13.23 \\
\hline Control & 3.61 & 0.61 & 16.02 & 13.15 \\
\hline $\begin{array}{l}\mathrm{CD} \\
(p=0.05)\end{array}$ & 0.58 & 0.086 & 0.015 & 0.12 \\
\hline
\end{tabular}


et al. (1999) observed a high degree of correlation between phosphorous uptake and activity of phosphatases. Earlier studies by Bethlenfalvay (1993) also show that different species and strains of AMF differ in their effectiveness in increasing nutrient uptake and plant growth. The pattern of extra-and intra-radical forms of AMF hyphae can also justify the difference in phosphorus acquisition among the AMF isolates. Hence, the level of development of extra-radical mycelium in the soil is a major determinant of the efficiency of AMF for phosphorus uptake (Rakshit and Bhadoria, 2010). Similar results indicating that phosphorus uptake by mycorrhizal plants fluctuate with fungal isolates and genetic variability; have also been found on soybean cultivars (Diop et al., 2003). The nitrogen and phosphorus transfer to the maize plants may also be a consequence of the competitive demand for the nutrients, with both host plant and fungus evolving transporters to take advantage of the localized increase in nutrients.

\subsection{P content in straw and grain}

Phosphorus content in straw and grain was found to be highest

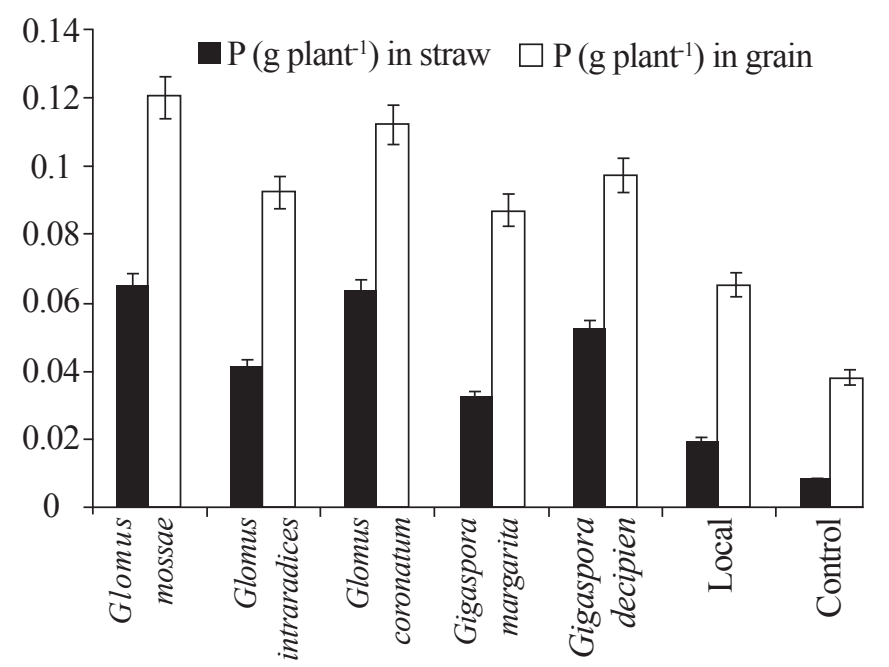

Figure 2: Effect of AM fungi on P uptake by straw and grain under G. mosseae inoculation (Figure 3). It might be due to the solubilization of unavailable phosphorus and increase in phosphorus uptake through plants root since mycorrhiza is responsible for increase in the surface area of roots. About 95$99 \%$ of the total $\mathrm{P}$ in soil exists in insoluble form unavailable to plants. The remaining soluble $\mathrm{P}$ is mostly present on exchangeable sites in equilibrium with the small amount of $\mathrm{P}$ in the soil solution. Therefore any solubilization of insoluble P by AM fungi significantly adds to the available pool. These results corroborate with the results of Gui et al. (2011) who reported that inoculation of $G$. mosseae significantly increased plant $\mathrm{P}$ concentration over un-inoculated maize plants.

\subsection{Correlation of estimated soil parameters}

The relationships of soil $\mathrm{pH}$, organic $\mathrm{C}$, Available N, P, K and DTPA extractable cationic micronutrients were determined. All the other parameters showed a significant negative association with soil $\mathrm{pH}$, thereby indicating that there was a reciprocal relationship between $\mathrm{pH}$ and all other attributes. The organic carbon content exhibited significant positive correlation with

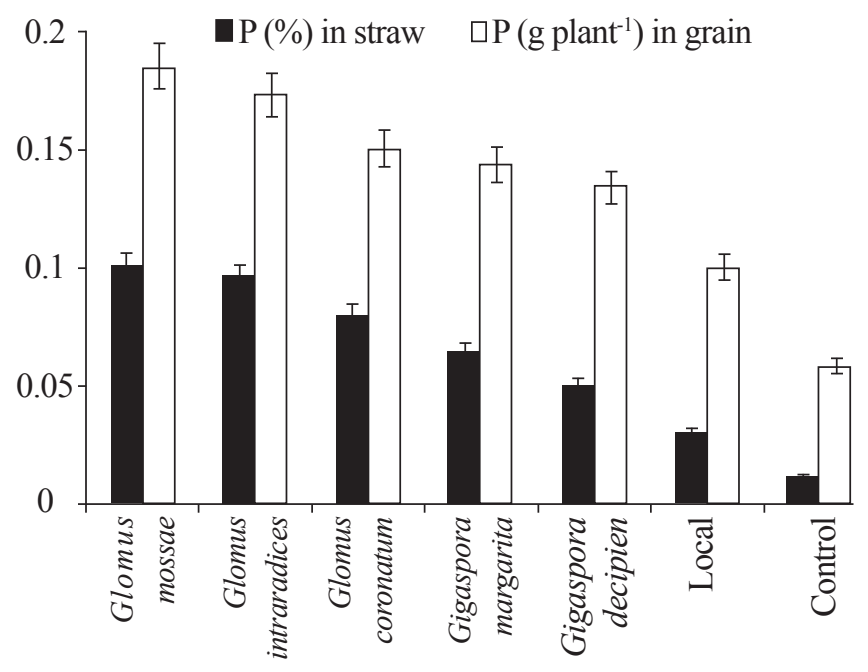

Figure 3: Effect of AM fungi on Phosphorus (P) concentration

Table 4: Correlation between different parameters

\begin{tabular}{|c|c|c|c|c|c|c|c|c|c|}
\hline & $\begin{array}{c}\text { Available } \\
\text { N }\end{array}$ & $\begin{array}{c}\text { Available } \\
\text { P }\end{array}$ & $\begin{array}{l}\text { Avail- } \\
\text { able K }\end{array}$ & $\begin{array}{c}\text { Organic } \\
\mathrm{C}\end{array}$ & $\begin{array}{c}\text { Available } \\
\text { Zn }\end{array}$ & $\begin{array}{l}\text { Avail- } \\
\text { able Cu }\end{array}$ & $\begin{array}{c}\text { Available } \\
\text { Fe }\end{array}$ & $\begin{array}{c}\text { Available } \\
\text { Mn }\end{array}$ & $\mathrm{pH}$ \\
\hline Available $N$ & 1 & $0.965^{* *}$ & $0.938^{* *}$ & $0.814^{* *}$ & $0.936^{* *}$ & $0.938^{* *}$ & $0.969^{* *}$ & $0.989^{* *}$ & $-0.905^{* *}$ \\
\hline Available $P$ & $0.965^{* *}$ & 1 & $0.941^{* *}$ & $0.840^{* *}$ & $0.936^{* *}$ & $0.927^{* *}$ & $0.935^{* *}$ & $0.974^{* *}$ & $-0.968^{* *}$ \\
\hline Available $K$ & $0.938^{* *}$ & $0.941^{* *}$ & 1 & $0.960^{* *}$ & $0.907^{* *}$ & $0.973^{* *}$ & $0.978^{* *}$ & $0.913^{* *}$ & $-0.933^{* *}$ \\
\hline Organic C & $0.814^{* *}$ & $0.840^{* *}$ & $0.960^{* *}$ & 1 & $0.808^{* *}$ & $0.923^{* *}$ & $0.889^{* *}$ & $0.782^{* *}$ & $-0.857^{* *}$ \\
\hline Available Zn & $0.936^{* *}$ & $0.936^{* *}$ & $0.907^{* *}$ & $0.808^{* *}$ & 1 & $0.964^{* *}$ & $0.908^{* *}$ & $0.934^{* *}$ & $-0.842^{* *}$ \\
\hline Available $\mathrm{Cu}$ & $0.938^{* *}$ & $0.927^{* *}$ & $0.973^{* *}$ & $0.923^{* *}$ & $0.964^{* *}$ & 1 & $0.954^{* *}$ & $0.909^{* *}$ & $-0.867^{* *}$ \\
\hline Available Fe & $0.969^{* *}$ & $0.935^{* *}$ & $0.978^{* *}$ & $0.889^{* *}$ & $0.908^{* *}$ & $0.954^{* *}$ & 1 & $0.941^{* *}$ & $-0.916^{* *}$ \\
\hline Available Mn & $0.989^{* *}$ & $0.974^{* *}$ & $0.913^{* *}$ & $0.782^{*}$ & $0.934^{* *}$ & $0.909^{* *}$ & $0.941^{* *}$ & 1 & $-0.914^{* *}$ \\
\hline $\mathrm{pH}$ & $-0.905^{* *}$ & $-0.968^{* *}$ & $-0.933^{* *}$ & $-0.857^{* *}$ & $-0.842^{* *}$ & $-0.867^{* *}$ & $-0.916^{* *}$ & $-0.914^{* *}$ & 1 \\
\hline
\end{tabular}


soil available macronutrient and cationic micronutrients content. This positive correlation with organic carbon indicated that cationic micronutrients formed complexes with organic matter and consequentially remained in the forms, easily available to the plants. The significant coefficient of correlation between macronutrients and organic matter content was in accordance with the findings of El-Fayoumy and Ramadan, 2002.

\section{Conclusion}

Inoculation of $\mathrm{AM}$ would be more attributed to nutrient availability in soil rhizosphere. It also contributed to relative better plant growth and higher uptake of phosphorus. As evident from the results, the AM fungal inoculation can effectively increase the solubility of micronutrients and plant phosphorus uptake. In the present experiment, the mycorrhizal inoculum, Glomus mosseae was found to cater important role in nutrient acquisition in rhizospheric soil of maize plant.

\section{Acknowledgment}

This work is a part of an ongoing research project "Evalution of AM fungi on phosphorus dynamics under maize rhizospheric soil" which is financially supported by the Bihar Agricultural University, Bihar, India. Authors are grateful to Vicechancellor, Bihar Agricultural University (BAU), Sabour, Bihar, India for providing financial assistance and necessary facilities to carry out this investigation.

\section{References}

Anonymous. 2005. Department of Agriculture and Cooperation: Statistics at a Glance, Government of West Bengal, Writers' Building, Kolkata http://www.wbgov. nic.in.

Archana, J., Amanullah, M.M., Manoharan, S., Subramanian, K.S., 2012. Influence of iron and arbuscular mycorrhiza inoculation on growth and yield of hybrid maize in calcareous soil. Madras Agricultural Journal 99, 65-67.

Balakrishnan, N., Subramanian, K.S., 2012. Mycorrhizal symbiosis and bioavailability of micronutrients in maize grain. Maydica 57, 129-138.

Bethlenfalvay, G.J., 1993. Mycorrhizae in the agricultural plant-soil system. Symbiosis 14(1-3), 413-414.

Bhadraiah, B., Kankadurga, V.V., Kankadurga, Ramrao, P., Ramrao, Manoharachary, C., 1999. Effect of VAM fungi and rock phosphate on phosphatase activities in Terminalia arjuna. National Conference on Mycorrhiza Section. Physiology and Biochemistry 5-7.

Black, C.A., 1965. Methods of soil analysis Part 2. Chemical and Microbiology Properties, 489-856.

Bouyoucos, J.B., 1962. Hydrometer method improved for making particle- size analysis of soils. Agronomy Journal 54, 464-465.

Chu, Q., Wang, X., Yang, Y., Chen, F., Zhang, F., Feng, G., 2013. Mycorrhizal responsiveness of maize (Zea mays L.) genotypes as related to releasing date and available P content in soil. Mycorrhiza 23(6), 497-505.

Covacevich, F., Echeverria, H.E., 2008. Receptivity of an Argentinean pampas soil to arbuscular mycorrhizal Glomus and Acaulospora strain. World Journal of Agricultural Science 4, 688-698.

Diop, T.A., Krasova-Wade, T., Diallo, A., Diouf, M., Gueye, M., 2003. Solanum cultivar responses to arbuscular mycorrhizal fungi: growth and mineral status. African Journal of Biotechnology 2(11), 429-433.

El-Fayoumy, M.E., Ramadan, H.M., 2002. Effect of Bioorganic manures on sandy soils amelioration and peanut productivity under sprinkler irrigation system. Egyptian Journal of Soil Science 42(3), 383.

Gianinazzi, S., Gollotte, A., Binet, M.N., Tuinen, D., Redecker, D., Wipf, D., 2010 Agroecology: the key role of arbuscular mycorrhizas in ecosystem services. Mycorrhiza 20, 519-530.

Gui, Y, Z., Li, P.Z., Ming, F.W., Zhen, L., Qiao, L.F., Qi, R.S., Guo. H.X., 2011. Effect of arbuscular mycorrhizal fungi, organic fertilizer and soil sterilization on maize growth. Acta Ecologica Sinica 31, 192-196.

Habasy, N.R., Abo-Zaid, M.M.A., 2005. Impact of Cd-Pb polluted water on growth and elemental composition of onion plants growth on a calcareous soil inoculated with mycorrhiza. Egyptian Journal of Applied Science 20, 586.

Hata, S., Kobae, Y., Banba, M., 2010. Interactions between plants and arbuscular mycorrhizal fungi. International Review Cell Molecular Biology 281, 1-48.

Hodge, A., Fitter, A.H., 2010. Substantial nitrogen acquisition by arbuscular mycorrhizal fungi from organic material has implications for $\mathrm{N}$ cycling. In: Proceedings of the National Academy of Sciences of the United States of Americ. 107, 13754-13759.

Jackson, M.L., 1973. Soil chemical analysis. New Delhi: Prentice-Hal of India.

Kaur, R., Singh, A., Kang, J.S., 2014. Influence of Different Types Mycorrhizal Fungi on Crop productivity. Current Agricultural Research 2(1): doi: http:/dx.doi. org/10.12944/CARJ. 2.107.

Kumari, Anop., Goyal, R.K., Sehrawat, S.K., Choudhary, Mahesh and Sindhu, S.S., 2014. Growth, yield and quality of chrysanthemum (Chrysanthemum morifolium Ramat.) cv. Dolly Orange as influenced by biofertilizers in combination with phosphorous. International Journal Agriculture Environment and Biotechnology 7(3), 
$555-564$.

Lindsay, W.L., Norvell, W.A., 1978. Development of DTPA soil test for Zn, Fe, Mn and Current Soil Science Society Ammerica Journal 42,421-428.

Mobasser, Hamid Reza., Moradgholi, Abolghasem., 2012. Mycorrhizal bio-fertilizer applications on yield seed corn varieties in Iran. Annals of Biological Research 3(2), 1109-1116.

Olsen, S.R., Cole, C.V., Watanabe, F.S., Dean, L.A., 1954. Estimation of available phosphorus in soils by extraction with sodium bicarbonate. U.S. Dep. of Agric. Circ. 939.

Olsson, Pal, Axel., Rahm, Jannice., Aliasgharzad, Nasser., 2010. Carbon dynamics inmycorrhizal symbioses is linked to carbon costs and phosphorus benefits. FEMS Microbiol Ecology 72, 123-131.

Parewa, H.P., Rakshit, A., Rao, A.M., Sarkar, N.C., Raha P. 2010. Evaluation of maize cultivars for phosphorus use efficiency in an Inceptisol. International Journal Agriculture Environment and Biotechnology 3, 195-198.

Rai, A., Rai, S., Rakshit, A., 2013. Mycorrhiza-mediated phosphorus use efficiency in plants Environment Experiment Biology 11, 107-117.

Rakshit, A., Bhadoria, P.S., 2010. Role of VAM on growth and phosphorus nutrition of maize with low soluble phosphate fertilization. Acta Agronomy 59(1), 119-123.

Smith, S.E., Smith, F.A., 2011. Roles of arbuscular mycorrhizas in plant nutrition and growth: new paradigms from cellular to ecosystems scales. Annual Review on Plant Biology 63, 227-250.

Smith, S.E., Read, D.J., 1997. Mycorrhizal Symbiosis. 2nd ed. Academic Press, London. 605. ISBN 0-12-652840-3.

Subbiah, B.V., Asija, G.L., 1956. A rapid procedure for estimation of available nitrogen in soils. Current Science $25,259-260$.

Tanwar, A., Aggarwal, A., 2013. Multifaceted potential of bioinoculants on red bell pepper (F1 hybrid, Indam Mamatha) production. Journal Plant Interaction DOI:10.1080/17429145.2013.7 65044.

Walkley, A., Black, I.A., 1934. An examination of the Degtjareff method for determining soil organic matter and a proposed modification of chromic acid titration method. Soil Science 37, 29-38.

Xu, Ping., Liang, Lin, Zhou., Dong, Xiao, Ying., Shen, Ren, Fang., 2014. Effect of arbuscular mycorrhizal fungi on aggregate stability of a clay soil inoculating with two different host plants. Acta Agriculturae Scandinavica, Section B-Soil and Plant Science 23-2. 